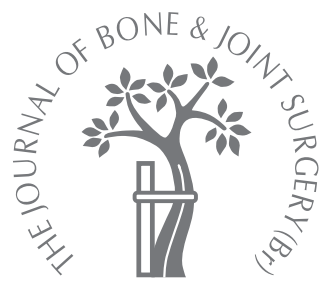

REVIEW ARTICLE

\title{
Percutaneous vertebroplasty and balloon kyphoplasty for the treatment of osteoporotic vertebral compression fractures and osteolytic tumours
}

A. G. Hadjipavlou, M.N.Tzermiadianos, P. G. Katonis, M. Szpalski

From the University Hospital of Crete, Heraklion, Crete, Greece
A. G. Hadjipavlou, MD, Professor and Chairman M. N. Tzermiadianos, MD, Orthopaedic Surgeon P. G. Katonis, MD, Assistant Professor Department of Orthopaedics University Hospital of Crete, P. O. Box 1352, Heraklion 71110, Crete, Greece.

M. Szpalski, MD, Associate Professor and Chairman Department of Orthopaedics Iris South Teaching

Hospitals, Brussels, Belgium.

Correspondence should be sent to Dr A. G. Hadjipavlou; e-mail:

ahadjipa@med.uoc.gr

(C)2005 British Editorial Society of Bone and Joint Surgery

doi:10.1302/0301-620X.87B12. $16074 \$ 2.00$

$J$ Bone Joint Surg $[\mathrm{Br}]$

2005;87-B:1595-604.
Back pain is the principal manifestation of most osteoporotic vertebral compression fractures, and may be either acute and excruciating, or chronic and persistent. ${ }^{1,2}$ Acute back pain, usually caused by a recent osteoporotic vertebral compression fracture, is expected to subside as the fracture heals, over a period of approximately three months. ${ }^{3}$ However, it is estimated that one-third ${ }^{4}$ to three-quarters ${ }^{5}$ of such patients may then develop chronic back pain. The causes may be attributed to pseudarthrosis or to osteoporotic spinal deformity such as kyphosis or kyphoscoliosis engendering a kaleidoscope of problems. The degree of kyphosis correlates well with the patient's physical function, the risk of further fractures, ${ }^{6,7}$ compression of the spinal cord, mental well-being and pulmonary function, ${ }^{8}$ any of which may contribute to an increased mortality rate. ${ }^{7,9,10}$ Conservative treatment cannot address the deformity. Major reconstructive surgery is indicated for crippling deformity and for neurocompression. ${ }^{11}$

Percutaneous vertebroplasty was designed and introduced for the management of osteolytic tumours, ${ }^{12-15}$ and later was successfully applied to osteoporotic vertebral compression fractures. ${ }^{4,16-18}$ It has also been shown to be valuable in the treatment of osteogenesis imperfecta, ${ }^{19}$ and has been used for focal Paget's disease of the spine refractory to medical treatment. ${ }^{20}$ The technique is well described in the literature. ${ }^{15,17,21,22}$

Percutaneous balloon kyphoplasty is a more recent technique which applies the principles of balloon angioplasty to vertebroplasty. It was primarily devised for the treatment of osteoporotic vertebral compression fractures, and subsequently used in the treatment of metastatic osteolytic tumours. ${ }^{23-25}$

\section{Methodology of review}

We have carried out a systematic review of work published between 1983 and September 2004. Of the 241 published studies (p), 146 were considered to be suitable for the present study (ps), based on complete data on outcome, complications, specific indications, case reports of rare complications and biomechanical and research studies. We found 38 case reports and accepted 23 for this study, eight case series for percutaneous vertebroplasty which were prospective but not randomised and 45 case series reviewed retrospectively. We also included case series of percutaneous balloon kyphoplasty as follows: prospective nonrandomised $(\mathrm{p}=17, \mathrm{ps}=17)$ and retrospective studies $(p=7$, $p s=7)$. We have included comparison studies as follows: between percutaneous vertebroplasty and percutaneous balloon kyphoplasty (retrospective, $\mathrm{p}=1, \mathrm{ps}=1$ ), between percutaneous vertebroplasty and conservative treatment (prospective, non-randomised, $\mathrm{p}=1, \mathrm{ps}=1$ ), between percutaneous balloon kyphoplasty and conservative treatment (prospective non-randomised, $\mathrm{p}=2, \mathrm{ps}=2$, and retrospective, $p=1, p s=1$ ). Many review articles and personal communications $(\mathrm{p}=77$, ps $=5$ ), and biomechanical and basic research papers $(\mathrm{p}=39$, $\mathrm{ps}=31)$ have been published. Finally, studies on radiation exposure during fluoroscopy have been reported ( $\mathrm{p}=5, \mathrm{ps}=5)$.

Studies have been combined in order to compare percutaneous vertebroplasty with percutaneous balloon kyphoplasty using metaregression techniques (random effects logistic regression, treating procedure type - percutaneous vertebroplasty versus percutaneous balloon kyphoplasty as a fixed and as a random effect). The comparison was extremely difficult, or in some cases impossible, because of the different tools and standards which were employed.

\section{Selection of patients}

It is important to distinguish pain caused by a vertebral compression fracture from other causes of back pain. This requires a careful correlation of the patient's history with clinical examination and available imaging. 
Table I. Efficacy of vertebroplasty in reducing pain in osteoporotic vertebral compression fracture (OVCF) and osteolytic metastatic tumours

\begin{tabular}{|c|c|c|c|c|c|c|}
\hline Authors & $\begin{array}{l}\text { Number of } \\
\text { patients }\end{array}$ & $\begin{array}{l}\text { Number of } \\
\text { vertebral bodies }\end{array}$ & Indication & $\begin{array}{l}\text { Patients with good to } \\
\text { excellent pain response } \\
(\%)\end{array}$ & $\begin{array}{l}\text { Pain reduction } \\
\text { (visual analogue } \\
\text { scale) }\end{array}$ & $\begin{array}{l}\text { Study } \\
\text { design }^{\dagger}\end{array}$ \\
\hline \multicolumn{7}{|l|}{ OVCF series } \\
\hline Jensen et $\mathrm{al}^{17}$ & 29 & 47 & OVCF & 90 & & Retro \\
\hline Martin et al $\left.\right|^{98}$ & 9 & NR & OVCF & 77.7 & & Retro \\
\hline Cortet et $\mathrm{al}^{18}$ & 16 & 20 & OVCF & 88 & -6 & Prosp \\
\hline Cyteval et $\mathrm{al}^{4}$ & 20 & 23 & OVCF & 90 & & Prosp \\
\hline $\mathrm{O}^{\prime}$ Brien et $\mathrm{al}^{42}$ & 6 & 6 & OVCF & 83.3 & & Retro \\
\hline Barr et $\mathrm{al}^{99}$ & 38 & 70 & OVCF & 95 & & Retro \\
\hline Grados et $\mathrm{al}^{36}$ & 25 & 34 & OVCF & 96 & -4.3 & Retro \\
\hline Heini et $\mathrm{al}^{52}$ & 17 & 45 & OVCF & 100 & -4.30 & Prosp \\
\hline Maynard et al ${ }^{100}$ & 27 & 35 & OVCF & 93 & -7.4 & Retro \\
\hline Amar et al $^{101}$ & 97 & 258 & OVCF & 63 & & Retro \\
\hline Moreland, Landi and Grand ${ }^{102}$ & 35 & 53 & OVCF & 89 & & Retro \\
\hline Kaufmann et al ${ }^{103}$ & 75 & 122 & OVCF & & -7.5 & Retro \\
\hline McGraw et l $^{56}$ & 100 & 156 & OVCF & 97 & -6.9 & Prosp \\
\hline Peh, Gilula and Peck ${ }^{104}$ & 37 & 48 & OVCF & 97 & & Retro \\
\hline Kallmes et $\mathrm{al}^{54}$ & 41 & 63 & OVCF (T4 to T8) & & -8 & Retro \\
\hline Zoarski et al ${ }^{105}$ & 30 & 54 & OVCF & 96 & & Prosp \\
\hline Gaughen et $\mathrm{al}^{62}$ & 48 & 84 & OVCF & 95.2 & -7.6 & Retro \\
\hline Nakano et al ${ }^{106}$ & 16 & 17 & OVCF & 100 & -7.73 & Retro \\
\hline Ryu et al $^{59}$ & 159 & 347 & OVCF & 87 & & Retro \\
\hline Perez-Higueras et al ${ }^{107}$ & 13 & 27 & OVCF & 92.3 & -8 & Prosp \\
\hline Evans et al $^{43}$ & 245 & 554 & OVCF & & -5.5 & Retro \\
\hline Jang et $a^{47 \ddagger}$ & 16 & 16 & OVCF & 88 & -4.7 & Retro \\
\hline Diamond et $\mathrm{al}^{37}$ & 55 & 71 & OVCF & 96.3 & & Prosp \\
\hline Peh et $\mathrm{al}^{29 \dagger}$ & 18 & 19 & OVCF & 77.7 & & Retro \\
\hline Gangi et al ${ }^{108}$ & 187 & 289 & OVCF & 78 & & Retro \\
\hline \multirow[t]{2}{*}{ Brown et $\mathrm{al}^{34}$} & 41 & \multirow{2}{*}{186} & OVCF > 1 year & 80 & & Retro \\
\hline & 49 & & OVCF $<1$ year & 92 & & \\
\hline Chen et al ${ }^{109}$ & 70 & 87 & OVCF & 85.5 & -4.4 & Retro \\
\hline Winking et al $\mathrm{l}^{110}$ & 38 & 66 & OVCF & 92 & -5.2 & Prosp \\
\hline Legroux-Gerot et $\mathrm{al}^{73}$ & 16 & 21 & OVCF & 75 & -3.5 & Prosp \\
\hline Total & 1573 & 2818 & & Mean 90 (86.1 to 92.8$)$ & & \\
\hline \multicolumn{7}{|l|}{ Tumour series } \\
\hline Weill et al $^{51}$ & 37 & 52 & Tumours & 94 & & Retro \\
\hline Cotten et $\mathrm{al}^{15}$ and Cortet et al ${ }^{111}$ & 37 & 40 & Tumours & 97.3 & & Retro \\
\hline Martin et $a^{98}$ & 20 & NR & Tumours & 65 & & Retro \\
\hline Barr et al ${ }^{99}$ & 8 & 13 & Tumours & 50 & & Retro \\
\hline Fourney et $\mathrm{al}^{25}$ & 34 & 65 & Tumours & 86 & & Retro \\
\hline Winking et al ${ }^{112}$ & 28 & & Tumours & 83 & & Prosp \\
\hline Alvarez et $\mathrm{al}^{41}$ & 21 & 27 & Tumours & 81 & -6.30 & Retro \\
\hline Total & 185 & 197 & & Mean 86.2 (75.9 to 92.5$)$ & & \\
\hline \multicolumn{7}{|l|}{ OVCF + tumour series } \\
\hline Kim et $\mathrm{al}^{113}$ & 49 & 75 & OVCF + tumours & 90 & & Retro \\
\hline Mousavi et al ${ }^{58}$ & 21 & 33 & OVCF + tumours & & -6.3 & Retro \\
\hline Hodler, Peck and Gilula114 & 152 & 363 & OVCF + tumours & 86.1 & & Retro \\
\hline Total & 222 & 471 & & Mean 90.7 (76.5 to 96.7 ) & & \\
\hline
\end{tabular}

* in this and other tables, meta-analytic responses are summarised with random effects meta-analysis/logistic regression using SAS GLIMMIX macro (SAS Version 8.2, Cary, North Carolina). Study was the random effect and indication the fixed effect

† Retro, retrospective; Prosp, prospective

‡ only OVCF with pseudarthrosis

Clinical assessment. Local tenderness as a principal sign of symptomatic fracture of a vertebral body was analysed in two studies. Gaitanis et $\mathrm{al}^{26}$ found that tenderness over the spinous process corresponding to the level of the pathology was elicited in $100 \%$ of osteolytic tumours, and in $96 \%$ of compression fractures when correlated with MR findings of an acute fracture. On the other hand, Gaughen et al ${ }^{27}$ noted that local tenderness was not present in ten patients with findings on imaging suggestive of an acute fracture.

Imaging modalities. Flexion/extension or standing/supine lateral radiographs can reveal mobile fractures, particu- larly fresh fractures or pseudarthroses which are capable of postural correction by extension of the spine. Intravertebral clefts characterising pseudarthrosis can easily be missed when examining standing lateral radiographs since they may be seen in as few as $14 \%$ of pseudarthrotic vertebral bodies compared with $64 \%$ detectable by supine, cross-table radiography. ${ }^{28}$ Peh et al, ${ }^{29}$ in a retrospective study of lateral radiographs, reported vacuum phenomena in $9 \%$ of patients $(4.8 \%$ of the vertebral compression fractures) reflecting the poor sensitivity of lateral radiographs in detecting intravertebral clefts. In regard to the latter, 
Table II. Efficacy of kyphoplasty in reducing pain in osteoporotic vertebral compression fracture (OVCF) and osteolytic metastatic tumours

\begin{tabular}{|c|c|c|c|c|c|c|}
\hline Authors & $\begin{array}{l}\text { Number of } \\
\text { patients }\end{array}$ & $\begin{array}{l}\text { Number of } \\
\text { vertebral bodies }\end{array}$ & Indication & $\begin{array}{l}\text { Patients with good to } \\
\text { excellent pain response } \\
(\%)\end{array}$ & $\begin{array}{l}\text { Pain reduction } \\
\text { (visual analogue } \\
\text { scale) }\end{array}$ & $\begin{array}{l}\text { Study } \\
\text { design* }\end{array}$ \\
\hline \multicolumn{7}{|l|}{ OVCF series } \\
\hline Theodorou et al ${ }^{115}$ & 15 & 24 & OVCF & 100 & & Retro \\
\hline Wong et $\mathrm{al}^{116}$ & 85 & 143 & OVCF & 94 & & Retro \\
\hline Wilhelm et al ${ }^{117}$ & 34 & 56 & OVCF & & -4.3 & Prosp \\
\hline Phillips et $\mathrm{al}^{50}$ & 29 & 61 & OVCF & 96.6 & -8 & Prosp \\
\hline \multirow[t]{2}{*}{ Crandall et $\mathrm{al}^{33}$} & 23 & 40 & Acute OVCF & 90 & -3 & Prosp \\
\hline & 24 & 46 & Chronic OVCF & 87 & & Prosp \\
\hline Berlemann et $\mathrm{al}^{35}$ & 24 & 27 & OVCF & 96 & -6.9 & Retro \\
\hline Hillmeier et $\mathrm{al}^{118}$ & 102 & 192 & OVCF & 89 & & Prosp \\
\hline Gaitanis et $\mathrm{al}^{26}$ & 27 & 49 & OVCF & 96.5 & & Prosp \\
\hline Total & 363 & 638 & & Mean 93.6 (88.2 to 96.6 ) & & \\
\hline \multicolumn{7}{|l|}{ Tumour series } \\
\hline Dudeney et $\mathrm{al}^{24}$ & 18 & 55 & $\mathrm{MM}^{\dagger}$ & 100 & & Prosp \\
\hline Fourney et $\mathrm{al}^{25}$ & 15 & 32 & Tumours & 80 & & Retro \\
\hline Gaitanis et $\mathrm{al}^{26}$ & 5 & 12 & Tumours & 100 & -7 & Prosp \\
\hline Total & 38 & 99 & & Mean 92.8 (75.6 to 98.2 ) & & \\
\hline \multicolumn{7}{|l|}{ OVCF + tumour series } \\
\hline Lieberman et $\mathrm{al}^{23}$ & 30 & 70 & $\mathrm{OVCF}+\mathrm{MM}$ & 100 & & Prosp \\
\hline Garfin et al ${ }^{57}$ & 340 & 603 & OVCF + tumours & 90 & & Prosp $^{\ddagger}$ \\
\hline Ledlie and Renfro ${ }^{44}$ & 96 & 133 & OVCF + tumours & 98 & -7.20 & Retro \\
\hline Coumans et $\mathrm{al}^{72}$ & 78 & 188 & $\mathrm{OVCF}+\mathrm{MM}$ & & -3.6 & Prosp \\
\hline Weisskopf et $a^{38}$ & 22 & 37 & OVCF + tumours & & $-6.7(82)$ & Retro \\
\hline Rhyne et al ${ }^{119}$ & 52 & 82 & OVCF + tumours & & -6.26 & Retro \\
\hline Total & 618 & 1113 & & Mean 95.6 (89.1 to 98.3 ) & & \\
\hline
\end{tabular}

* Retro, retrospective; Prosp, prospective

$\dagger \mathrm{MM}$, multiple myeloma

‡ prospective multicentre

MRI is more sensitive than plain radiography with a reported accuracy of $96 \% .{ }^{28}$ However, Lane et al, ${ }^{30}$ in a retrospective analysis, reported intravertebral clefts in $31.8 \%$ of patients during percutaneous vertebroplasty, $52.8 \%$ of which had been detected on pre-operative MRI. By contrast, gas-filled clefts were seen in only $11.4 \%$ of pre-operative radiographs. MR is the most useful imaging technique for the detection of oedema indicating acute fracture. This is best depicted on sagittal MR images with short tau inversion recovery (STIR), ${ }^{31,32}$ which is also a good predictor of correction of deformity with balloon kyphoplasty. ${ }^{26}$

When patients are unable to tolerate MRI, ${ }^{99} \mathrm{Tc}$-methyldiphosphonate bone scanning combined with computerassisted tomography can provide useful information on relatively fresh vertebral fractures. Bone scanning may remain negative in patients with vertebral fractures with minimal loss of height, or remain positive for a prolonged period of time (up to two years) after healing of a fracture, reflecting remodelling.

\section{Measurements of outcome}

Clinical response. Both vertebroplasty and balloon kyphoplasty have been shown to be highly effective in reducing pain from both compression fractures and osteolytic tumours (Tables I and II). Most of the fractures treated are subacute and less than one year old. Although better results can be expected in more recent fractures, quite satisfactory results have been reported in chronic cases. ${ }^{33,34}$ No correla- tion was found between the degree of correction of the vertebral body with balloon kyphoplasty ${ }^{35}$ or the volume of cement injected, ${ }^{15}$ and the clinical outcome.

Regarding the long-term effect of vertebroplasty on pain, Grados et $\mathrm{al}^{36}$ reported good or excellent results in $96 \%$ of patients with a mean follow-up of 48 months (12 to 84). Diamond, Champion and Clark ${ }^{37}$ in a prospective non-randomised study, compared the outcome of 55 patients who underwent percutaneous vertebroplasty, with that of 24 who declined the procedure. Although there was a dramatic improvement in pain and physical function in the vertebroplasty group by 24 hours, after six weeks no difference could be detected between the groups. However, in this study the comparison was made with patients who had declined the surgical procedure, imposing a strong bias on the results.

The studies listed in Tables I and II have been combined in order to compare vertebroplasty with balloon kyphoplasty using meta-regression techniques. The design of the study appeared to have a considerable impact on the analysis. For prospective studies, the rates of success of vertebroplasty and kyphoplasty were equivalent at 92\% and 93\% respectively $(\mathrm{p}=0.6312)$. For retrospective studies, however, kyphoplasty appeared to be more successful (95\% vs $86 \% ; \mathrm{p}=0.019)$. Among retrospective studies, the success rates were higher when kyphoplasty was used for compression fractures and when compression fractures were combined with lytic tumours, but lower in the group of patients with lytic tumours alone. 
There was only one study available ${ }^{25}$ which directly compared vertebroplasty with kyphoplasty and this reported equivalent results in relieving pain. Unfortunately, this review is retrospective and is limited to patients with cancer. In the three studies which directly compared kyphoplasty with conventional medical treatment, ${ }^{38-40}$ kyphoplasty consistently improved the levels of pain and physical function and the results were sustained at six months.

From the available data regarding the management of pain it appears that kyphoplasty has given slightly more favourable results than vertebroplasty, but this does not reach statistical significance. Clearly, kyphoplasty gives better results than conventional standard medical treatment.

A major benefit of vertebral augmentation surgery was the restoration of mobility in $73 \%$ of 11 wheelchair-bound patients with cancer treated by vertebroplasty. ${ }^{41}$ In severely handicapped osteoporotic patients, restoration of mobility with vertebroplasty ranged from $80 \%{ }^{42}$ to $82 \%,{ }^{43}$ and with kyphoplasty from $84 \%{ }^{44}$ to $100 \% .{ }^{26}$

Restoration of vertebral height. The possible beneficial effects of vertebroplasty are attributed either to postural reduction of a mobile vertebra by hyperextension, or to the injection of viscous cement under pressure. Movement of fragments has been reported in $44 \%$ of patients with compression fractures (35\% of fractured vertebrae).$^{45}$ Most mobile fractures are seen at the thoracolumbar junction $(81 \%) .{ }^{46} \mathrm{Jang}$, Kim and Lee, ${ }^{47}$ in a series of patients with single mobile fractures, reported that the mean anterior vertebral height, measured on the standing flexion radiographs before operation, improved from $14.8 \mathrm{~mm}$ to $21.8 \mathrm{~mm}$ with extension of the spine. After vertebroplasty the mean anterior height was $19.8 \mathrm{~mm}$, suggesting that considerable reduction can be achieved by postural extension and preserved by vertebroplasty, with a slight loss of maximum correction (mean $2 \mathrm{~mm}$ ). Teng et $\mathrm{al}^{48}$ also reported that reduction is more pronounced in vertebrae seen to contain gas, with a mean wedge-angle reduction of $10.2^{\circ}$. However, Hiwatashi et al ${ }^{49}$ found that no patients with a substantial increase in the height of the vertebral body showed fluid- or gas-filled clefts on pre-operative MR images. They attributed the increase in height to the injection of high-viscosity cement under pressure and noted that it was more obvious in vertebrae with intact bony walls which appeared to prevent leakage.

Some of the variation in the results reported in studies of balloon kyphoplasty may be influenced by the age of the fracture and the degree of deformity. All the reports agree that the age of the fracture is the major determinant in achieving a satisfactory reduction. ${ }^{33,35}$ Some authors state that meaningful correction in height can be achieved in some fractures even older than three months, ${ }^{26,33,35}$ which seems predictable in cases of pseudarthrosis. Others contradict this assertion. ${ }^{50}$ Crandall et $\mathrm{al}^{33}$ reported failure of significant correction in $20 \%$ of chronic as opposed to $8 \%$ of acute fractures. The ability to restore vertebral height also improves with the amount of pre-operative kyphosis, and in patients with a more caudal location of the fracture. ${ }^{35}$ More data are needed to compare the two techniques in a prospective randomised fashion with a standardised and validated method.

\section{Complications}

Complications associated with vertebroplasty or kyphoplasty can be ascribed to the procedure itself or to cardiac and pulmonary problems, which are less common than following open surgical procedures.

Transient increase in pain. A transient increase in pain during vertebroplasty has been described, ${ }^{15,36,51}$ with an incidence varying between $4 \%{ }^{36}$ and $23.4 \% .^{52}$ This may be attributed to an increase in pressure in a painful vertebra, to an inflammatory reaction to polymethylmethacrylate (PMMA) or to osseous ischaemia. ${ }^{53}$

Infection. Kallmes et $\mathrm{a}^{54}$ described a case of infection with Staphylococcus epidermidis in a series of 41 patients treated by vertebroplasty for compression fracture. Yu et $\mathrm{al}^{55}$ reported a case of osteomyelitis in a patient who underwent vertebroplasty one week after infection of the urinary tract. This suggests that concurrent infection is a contraindication to both vertebroplasty and kyphoplasty.

Rib and sternal fractures. Rib fractures have been occasionally associated with vertebroplasty and kyphoplasty, ${ }^{17,23,43}$ and fracture of the sternum has also been seen after vertebroplasty. ${ }^{56}$

Surgeons and theatre personnel should avoid leaning over these frail patients who require delicate handling. Technical complications. Kallmes et $\mathrm{al}^{54}$ described a fracture of the pedicle occurring after faulty placement of instruments in one patient in their series of 41 , and Diamond et $\mathrm{a}^{37}$ noted two fractures of the transverse process in 55 patients having vertebroplasty. Other technical complications from the inappropriate placement of instruments during balloon kyphoplasty, have resulted in a breach of the pedicle and inadvertent leakage of cement into the spinal canal, a post-operative haematoma in two patients and injury to the spinal cord when an extrapedicular approach was used on a vertebra with a fractured pedicle. ${ }^{57}$ In these last three patients serious neurological complications developed, partial motor loss in the first two, and an anteriorcord syndrome in the third. Leakage of cement is the most serious potential complication.

Occasional rupture of the inflatable tamps during balloon kyphoplasty has been reported. In all instances the ruptured tamp was easily withdrawn without clinical consequences. ${ }^{23,26}$

Leakage of cement. Although leakage of cement is well tolerated in most cases, it is the main source of pulmonary and neurological complications. Reports of such leakage revealed on radiographs are less reliable than those reported by CT. It has been reported that extravasation of cement is more common when vertebroplasty is used for metastatic osteolytic tumours or myelomas. However, Vas- 


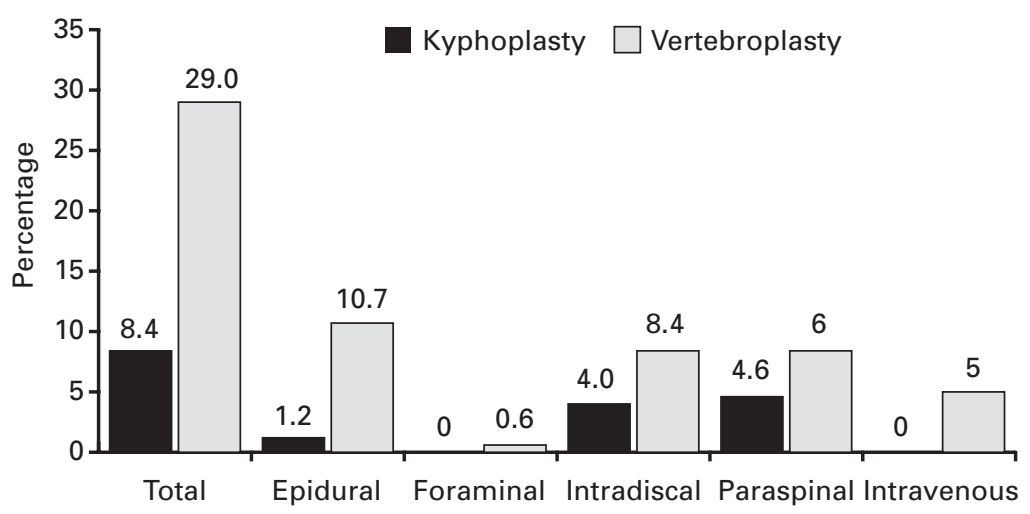

Fig. 1

Histogram depicting differences between kyphoplasty and percutaneous vertebroplasty in the percentage per location of cement extravasation. Cumulative data from 1279 vertebral bodies treated with kyphoplasty and 2729 vertebral bodies treated with vertebroplasty. concelos et $\mathrm{al}^{22}$ observed no major differences, although they noted venous leaks slightly more frequently in patients with metastatic lesions. When percutaneous vertebroplasty was performed for severely compressed vertebral bodies with fractured endplates, leakage from the disc space was more commonly observed. ${ }^{22}$ Mousavi et al $^{58}$ reviewing post-operative CT scans in patients with compression fractures and metastatic tumours, concluded that in osteoporotic vertebrae leakage occurred mainly into the disc, whereas in metastatic lesions it was found in many areas.

In studies on vertebroplasty, epidural leakage of PMMA cement is reported to occur more often in levels above T7. ${ }^{59}$ The risk of extravasation of cement into veins and into the epidural space increases with the volume of the cement injected. ${ }^{59}$ Some authors advise against attempts to inject more than $5 \mathrm{ml}$ of PMMA into one vertebra. ${ }^{60}$ Although McGraw et $\mathrm{al}^{56}$ found that intraosseous venography predicted the flow of PMMA during vertebroplasty in $83 \%$ of cases, this has not been confirmed by others, and the use of venography has largely been abandoned ${ }^{61-63}$ except in hypervascular tumours. The viscosity of the cement has been shown to represent the most important factor in extravasation. ${ }^{64}$ Heini et $\mathrm{al}^{21}$ felt that the risk of intravascular extravasation is diminished if the flow of cement is directed medially. They suggested the use of a side-opening cannula.

Tsai et $\mathrm{al}^{65}$ reported an anterior displacement of cement, one month after percutaneous vertebroplasty for a compression fracture with a fluid-filled intravertebral cleft at T12. Balloon kyphoplasty creates a cavity which allows a more viscous cement to be inserted slowly thereby decreasing the risk of extravasation. Inflation of the balloon compacts the trabecular bone, which may seal osseous defects or venous pathways. This hypothesis was confirmed by Phillips et al, ${ }^{66}$ who injected contrast material before and after balloon inflation in 20 kyphoplasties for compression fracture. Fourney et al, ${ }^{25}$ treating metastatic lesions, reported an incidence of $9 \%$ of leakage in vertebroplasty, but none in balloon kyphoplasty. Studies on cadavers also showed a reduced rate of leakage in kyphoplasty. Belkoff et al ${ }^{67}$ noted extravertebral leakage of cement from five of eight fractured vertebral bodies in human cadavers treated by vertebroplasty, but no leakage during kyphoplasty.

These reports give strong evidence that kyphoplasty is safer than vertebroplasty (Fig. 1). The widely variable incidence of extravasation of cement during augmentation procedures, and the more accurate detection by CT, suggests that this complication is probably more common than is recognised.

\section{Clinical complications of leakage of cement}

Pulmonary embolism. In an experimental sheep model, Aebli et $a^{68}$ demonstrated the potentially serious cardiovascular complications that can be caused by fat embolism during vertebroplasty, regardless of the augmentation material. Augmentation of more than one vertebral body is associated with a cumulative incidence of embolic phenomena. The reasons for these complications are mainly related to the increase in intraosseous pressure during augmentation, causing propulsion of bone-marrow contents into the circulation, or to reduction of the sympathetic tone, rather than to the methylmethacrylate monomer. ${ }^{69}$ Placement of a needle as a vent in the contralateral pedicle has been advocated during the injection of cement. ${ }^{70}$ In a retrospective study of 78 patients, Kaufmann et $\mathrm{al}^{71}$ reported a significant but transient drop in oxygen saturation for ten minutes after vertebroplasty. There is only one reported case of non-fatal cement pulmonary embolism after kyphoplasty reported in the literature. ${ }^{57}$

Based on the recognised toxicity of PMMA when spilled into the venous circulation, some authors recommend that the maximum volume of injected cement should not exceed $30 \mathrm{ml}$ or three levels per session. ${ }^{72}$ However this may be excessively cautious in balloon kyphoplasty since the cement can be inserted in a very viscous state. In our series 11 patients underwent five levels and two six levels at the same sitting without untoward effects on the blood pressure or blood gases.

Neurological complications. Although leakage of cement into the spinal canal is well tolerated in most cases, it can occasionally lead to serious neurological complications and 
even paraplegia. Intraforamenal leakage is more harmful. Cotten et $\mathrm{al}^{15}$ found that leakage from the spinal canal was well tolerated in all their 15 patients while two of eight cases of foraminal leakage were associated with radiculopathy. Transient femoral neuropathy have been reported after leakage of PMMA into the psoas muscle., ${ }^{4,15}$ In most cases, however, the symptoms are transient and respond well to nerve-root blocks, or oral medication; rarely do they require surgical decompression. ${ }^{4,15,51}$ From these reports it is apparent that kyphoplasty fares better than vertebroplasty in terms of neurological complications.

Adjacent fractures. A number of reports indicate an increased risk of secondary fractures adjacent to the augmented vertebra. The odds ratio for a vertebral fracture in the vicinity of a cemented vertebra has been reported to be between $3.18^{73}$ and $2.27,,^{36}$ compared with $2.14^{73}$ to $1.44^{36}$ in the vicinity of an uncemented fracture. The greater the degree of augmentation of the treated vertebra and the location of the adjacent vertebra at the thoracolumbar junction are considered to be risks for secondary vertebral body fractures. $^{74}$

Lin et $\mathrm{al}^{75}$ found that $71.4 \%$ of patients with secondary fractures had intradiscal leakage of cement. In their study, vertebral bodies adjacent to a disc with leakage of cement had a $58 \%$ chance of developing a new fracture compared with $12 \%$ of vertebral bodies adjacent to a disc without leakage. ${ }^{75}$ Leakage into the disc, by impeding the flexibility, may increase the risk of a secondary fracture in an adjacent vertebral body.

Analysis of the incidence of secondary fractures after vertebroplasty in the series of Lin et $\mathrm{al}^{75}$ is made more difficult by lack of a mean period of follow-up. Assuming the mean to be about 12 months, and analysing for both numbers of patients and length of follow-up, random effects Poisson regression shows, on meta-analysis, a rate per patientmonth of $0.82 \%(0.45 \%$ to $1.49 \%)$. Appropriate metaanalysis of such an incidence after kyphoplasty is difficult because of the lack of a mean follow-up period in two studies.

Lindsay et $\mathrm{al}^{76}$ found a mean incidence of $19.2 \%$ of secondary vertebral fractures within one year of an initial vertebral fracture in patients with osteoporosis. In women with one previous fracture, the incidence was $11.5 \%$, whereas $24 \%$ of the women with two or more fractures had a new fracture within the following year. Silverman et $\mathrm{al}^{77}$ reported that $58 \%$ of women with one or more fractures had adjacent fractures.

A kyphotic deformity moves the centre of gravity forwards resulting in an increased forward bending moment which increases the load within the kyphotic angle and predisposes adjacent vertebrae to suffer secondary fractures. Reduction of deformity with kyphoplasty may be expected to decrease the risk of new fractures. This view is supported by two small, prospective, non-randomised studies which compared kyphoplasty with conservative treatment. In the first, Kasperk et $\mathrm{al}^{40}$ found that at follow-up at six months,
$30 \%$ of 20 patients who had been treated conservatively developed secondary fractures, compared with $12.5 \%$ of 40 patients who had undergone kyphoplasty. The incidence of fractures at adjacent levels was also reduced from $12 \%$ to $6 \%$. Similarly, Komp et al ${ }^{39}$ reported that at follow-up at six months, the incidence of new fractures in 17 conservatively-treated patients was $65 \%$ compared with $37 \%$ in 19 patients treated by kyphoplasty.

The rates of new fracture after cement augmentation procedures are not comparable between vertebroplasty ( $0 \%$ to $52 \%)$, kyphoplasty $(5.8 \%$ to $36.8 \%$ ) and conservatively-treated patients $(19.2 \%$ to $58 \%)$, because of the poor scientific design of the studies. Most are retrospective or non-randomised prospective reports.

\section{Laboratory studies}

It has been suggested that the increased strength of a vertebral body after vertebroplasty would lead to a greater risk of fracture of an adjacent vertebral body. ${ }^{78,79}$ The biomechanical properties of various cement augmentations have been investigated. There is some variation between the value of compressive stiffness and strength, according to various investigators. The greater values described by Tomita et $a l^{80}$ may be explained by the fact that the weak osteoporotic bone of the original vertebra will show a greater improvement in strength after kyphoplasty or vertebroplasty. Restoration of stiffness is reported to be loosely associated with the volume of cement injected, ${ }^{81}$ and this may explain the discrepancies between various studies. Tomita et $\mathrm{al}^{80}$ attributed the increased vertebral strength and decreased stiffness after kyphoplasty or vertebroplasty to the presence of cancellous bone remaining between the end-plate and bone cement. Sufficient cement should be injected between the end-plates and a plausible mechanical explanation for the disparity of the results among various investigators may be in the use of different volumes of cement.

Heini et $\mathrm{al}^{82}$ and Tomita et $\mathrm{al}^{80}$ observed that the lower the initial bone mineral density is, the more pronounced is the augmentation effect. In strong non-osteoporotic bone, cement augmentation does not produce any significant changes. ${ }^{82}$ In cadavers, the amount of cement sufficient to restore the mid thoracic vertebral strength is between $2 \mathrm{ml}^{83}$ and $2.5 \mathrm{ml} ;^{84}$ for the thoracolumbar spine, between $2.5 \mathrm{ml}^{84}$ and $4 \mathrm{ml}^{83}$ and for the lumbar spine $3.1 \mathrm{ml}^{84}$ to $6 \mathrm{ml} .{ }^{83}$ To restore compressive stiffness, the quantity of cement was $4 \mathrm{ml}$ for the thoracic spine according to two studies, ${ }^{83,84}$ varying between $4 \mathrm{ml}^{84}$ and $8 \mathrm{ml}^{83}$ for the thoracolumbar region, and $8 \mathrm{ml}^{84}$ for the lumbar region. Liebschner, Rosenberg and Keaveny ${ }^{85}$ demonstrated that $14 \%$ of the volume of a vertebral body, or less than $3 \mathrm{ml}$ of bone cement, are required to restore compressive stiffness in vertebroplasty. A quantity greater than $30 \%$ of the volume of a vertebral body will substantially increase compressive stiffness. Molloy et $\mathrm{al}^{83}$ reported comparable measurements. Tohmeh et $\mathrm{al}^{86}$ stated that unipedicular 
insertion of cement gives results comparable with those following a bipendicular approach; but, Liebschner et al ${ }^{85}$ preferred the latter.

The optimal augmentation, yet to be quantified, would provide sufficient local strength and stiffness without predisposing to fracture of adjacent vertebrae.

\section{Exposure to radiation}

During vertebroplasty, radiation doses of 0.022 to $3.256 \mathrm{mGy}$ outside and 0.01 to $0.47 \mathrm{mGy}$ inside the lead apron have been reported. ${ }^{87}$ The dose on the operator's hand ranged between 0.5 and $8.5 \mathrm{mGy}$ indicating greater exposure to the operator's hands than expected from traditional apron measurement. ${ }^{87}$

Implementation of protective measures has been effective for reducing radiation. ${ }^{87-89}$ When these were used, the mean whole-body dose for vertebroplasty was reduced from 1.44 to $0.004 \mathrm{mSv}$ per vertebrae, and the mean hand dose from $2.04 \mathrm{mSv}$ to $0.075 \mathrm{mSv}$ per vertebrae. Tests of shielding devices indicate a significant reduction in wholebody and hand doses ranging from $42.9 \%$ to $86 \% .{ }^{89}$ The use of an injection instrument also significantly decreases the radiation dose to the operator's hands. ${ }^{90}$

A recent report ${ }^{91}$ indicated that the mean total fluoroscopy time for kyphoplasty was 10.1 minutes (SD 2.2). The mean effective patient dose was 8.5 to $12 \mathrm{mSv}$, and the mean gonadal dose 0.04 to $16.4 \mathrm{mGy}$, depending on the level of the treated vertebrae. Skin damage after percutaneous kyphoplasty is improbable if the source-to-skin distance is $35 \mathrm{~cm}$ or more. However, problems may occur if the total fluoroscopy time per projection is extended and/or the source-to-skin distance during the procedure is less than $35 \mathrm{~cm}$.

\section{Overview}

Osteoporosis is not a benign process of ageing, but is associated with variety of disabling symptoms, ranging from mild local discomfort to crippling spinal deformity, occasionally associated with serious neurological deficits and even paraplegia. ${ }^{11}$ As life expectancy continues to increase, vertebral compression fractures and metastatic osteolytic lesions will become an expanding health problem with enormous socio-economic costs. ${ }^{92}$ The indication for the surgical management should not be limited to pain, but should also address the spinal deformity. Since more reliable and complete reduction is achieved with early treatment, Yuan, Brown and Phillips ${ }^{93}$ have argued for prompt intervention. In patients with spinal metastases, cement augmentation provides immediate and substantial relief from pain, restores the osseous defect and structural strength of the collapsed vertebrae, particularly in kyphoplasty, and does not delay treatment with radiotherapy or chemotherapy. These benefits, quite apart from the relief from pain, should also be considered a strong argument for the prompt management of metastatic osteolytic tumours of the spine.
Although postural reduction can improve the vertebral height following a compression fracture, better results are obtained with kyphoplasty and vertebroplasty cannot be accepted as a safe technique. Radiological methods for measurement of the vertebral body height are imprecise and do not assess the global vertebral deformity. ${ }^{94}$ The data on restoration of the height of the vertebral body in both techniques are muddled because of the different methods used for assessment. ${ }^{95}$ Restoration of the sagittal alignment of the spine will bring about a change of the displaced centre of gravity backwards, thereby decreasing the risk for secondary fractures. The creation of a void within the vertebral body surrounded by impacted trabeculae allows the insertion of viscous bone cement with moderate pressure, obviating leakage of cement.

A disadvantage of kyphoplasty is the high cost of the equipment. $^{96,97}$ The procedure takes longer and is more painful than vertebroplasty, usually requiring general anaesthesia and more irradiation.

\section{Conclusions}

Both percutaneous vertebroplasty and balloon kyphoplasty have been shown to be effective in controlling pain and improving function. Similar results have also been obtained in the treatment of osteolytic tumours. Kyphoplasty has the advantage of improving or restoring the vertebral height and kyphotic deformity. However, approximately one-third of osteoporotic vertebral compression fractures are mobile. Satisfactory reduction can be achieved by hyperextending the patient's spine on the operating table and using kyphoplasty to maintain the reduction.

Leakage of cement, rare after kyphoplasty, seems to be a common complication of vertebroplasty. It is well tolerated in most cases but it can lead to serious neurological and pulmonary complications. Augmentation of the vertebral body by PMMA cement restores the strength and increases the stiffness of the vertebrae and may predispose the adjacent vertebral bodies to new fractures.

The ideal amount of augmentation necessary to restore a desirable degree of local strength and stiffness has not been established.

\section{Supplementary Material}

$\because$ Tables showing a comparison of studies between balloon kyphoplasty and percutaneous vertebroplasty, the mean restoration of height after balloon kyphoplasty and percutaneous vertebroplasty, the incidence and location of cement leakage during balloon kyphoplasty and percutaneous vertebroplasty, the reported cases of pulmonary embolism during cement augmentation procedures, the neurological complications after percutaneous vertebroplasty, the incidence of vertebral body fractures after balloon kyphoplasty and percutaneous vertebroplasty and the biomechanical properties of bone-cement augmentation of vertebral bodies are available with the electronic version of this article on our website at www.jbjs.org.uk 


\section{References}

1. Lyritis GP, Mayasis B, Tsakalakos N, et al. The natural history of osteoporotic vertebral fracture. Clin Rheumatol 1989;8(Suppl 2):66-9.

2. Sinaki M. Exercise and physical therapy. In: Riggs L, Melton J, eds. Osteoporosis: etiology, diagnosis and management. New York: Raven Press, 1988:401.

3. Eck JC, Hodges SD, Humphreys SC. Vertebroplasty: a new treatment strategy for osteoporotic compression fractures. Am J Orthop 2002;31:123-8.

4. Cyteval C, Sarrabere MP, Roux J0, et al. Acute osteoporotic vertebral collapse: open study on percutaneous injection of acrylic surgical cement in 20 patients. AJR Am J Roentgenol 1999;173:1685-90.

5. OId JL, Calvert M. Vertebral compression fractures in the elderly. Am Fam Physician 2004:69:111-16

6. Pluijm SM, Tromp AM, Smit JH, Deeg DJ, Lips P. Consequences of vertebral deformities in older men and women. J Bone Miner Res 2000;15:1564-72.

7. Kado DM, Browner WS, Palermo L, et al. Vertebral body fractures and mortality in older women: a prospective study. Arch Intern Med 1999;159:1215-20.

8. Schlaich C, Minne HW, Bruckner T, et al. Reduced pulmonary function in patients with spinal osteoporotic fractures. Osteoporos Int 1998;8:261-7.

9. Linville DA 2nd. Vertebroplasty and kyphoplasty. South Med J 2002;95:583-7.

10. Cotten A, Boutry N, Cortet B, et al. Percutaneous vertebroplasty: state of the art. Radiographics 1998;18:311-20.

11. Hadjipavlou AG, Katonis PG, Tzermiadianos MN, Tsoukas GM, Sapkas G. Principles of management of osteometabolic disorders affecting the aging spine. Eur Spine J 2003;12(Suppl 2):113-31.

12. Galibert $\mathbf{P}$, Deramond $\mathbf{H}$, Rosat $\mathbf{P}$, Le Gars $\mathbf{D}$. Preliminary note on the treatment of vertebral angioma by percutaneous acrylic vertebroplasty. Neurochirurgie 1987;33: 166-8 (in French).

13. Kaemmerlen $\mathbf{P}$, Thiesse $\mathbf{P}$, Bouvard $\mathbf{H}$, et al. Percutaneous vertebroplasty in the treatment of metastases: technic and results. J Radiol 1989;70:557-62 (in French).

14. Kaemmerlen $\mathbf{P}$, Thiesse $\mathbf{P}$, Jonas $\mathbf{P}$, et al. Percutaneous injection of orthopaedic cement in metastatic vertebral lesions. N Engl J Med 1989;321:121.

15. Cotten A, Dewatre F, Cortet B, et al. Percutaneous vertebroplasty for osteolytic metastases and myeloma: effects of the percentage of lesion filling and the leakage of methylmethacrylate at clinical follow-up. Radiology 1996;200:525-30.

16. Lapras C, Mottolese C. Deruty R, et al. Percutaneous injection of methyl-methacrylate in the treatment of severe vertebral osteolysis (Galibert's technic). Ann Chir 1989;43:371-6 (in French).

17. Jensen ME, Evans AJ, Mathis JM, et al. Percutaneous polymethylmethacrylate vertebroplasty in the treatment of osteoporotic vertebral body compression fractures: technical aspects. AJNR Am J Neuroradiol 1997:18:1897-904.

18. Cortet B, Cotten A, Boutry N, et al. Percutaneous vertebroplasty in the treatment of osteoporotic vertebral compression fractures: an open prospective study. J Rheumatol 1999;26:2222-8.

19. Rami PM, McGraw JK, Heatwole EV, Boorstein JM. Percutaneous vertebroplasty in the treatment of vertebral body compression fracture secondary to osteogenesis imperfecta. Skeletal Radiol 2002;31:162-5

20. Kremer MA, Fruin A, Larson TC 3rd, Roll J, Weil RJ. Vertebroplasty in focal Pagel disease of the spine: case report. J Neurosurg Spine 2003;99:110-13.

21. Heini PF, Dain Allred C. The use of a side-opening injection cannula in vertebroplasty: a technical note. Spine 2002;27:105-9.

22. Vasconcelos C, Gailloud P, Beauchamp NJ, Heck DV, Murphy KJ. Is percutaneous vertebroplasty without pretreatment venography safe: evaluation of 205 consecutive procedures. AJNR Am J Neuroradio/ 2002;23:913-17.

23. Lieberman IH, Dudeney S, Reinhardt MK, Bell G. Initial outcome and efficacy of "kyphoplasty" in the treatment of painful osteoporotic vertebral compression fractures. Spine 2001;26:1631-738.

24. Dudeney S, Lieberman IH, Reinhardt MK, Hussein M. Kyphoplasty in the treatment of osteolytic vertebral compression fractures as a result of multiple myeloma. J Clin Oncol 2002;20:2382-7.

25. Fourney DR, Schomer DF, Nader R, et al. Percutaneous vertebroplasty and kyphoplasty for painful vertebral fractures in cancer patients. J Neurosurg Spine 2003;98: 21-30.

26. Gaitanis I, Hadjipavlou AG, Katonis PG, et al. Balloon kyphoplasty for the treatment of pathological vertebral compressive fractures. Eur Spine J 2005;14:250-60.

27. Gaughen JR Jr, Jensen ME, Schweickert PA, et al. Lack of preoperative spinous process tenderness does not affect clinical success of percutaneous vertebroplasty. $J$ Vasc Interv Radio/ 2002;13:1135-8.

28. McKiernan F, Faciszewski T. Intravertebral clefts in osteoporotic vertebral compression fractures. Arthritis Rheum 2003;48:1414-19.

29. Peh WC, Gelbart MS, Gilula LA, Peck DD. Percutaneous vertebroplasty: treatment of painful vertebral compression fractures with intraosseous vacuum phenomena. AJR Am J Roentgenol 2003;180:1411-17.
30. Lane JI, Maus TP, Wald JT, et al. Intravertebral clefts opacified during vertebroplasty: pathogenesis, technical implications, and prognostic significance. AJNRAm J Neuroradial 2002;23:1642-6

31. Meyers SP, Wiener SN. Magnetic resonance imaging features of fractures using the short tau inversion recovery (STIR) sequence: correlation with radiographic findings. Skeletal Radiol 1991;20:499-501.

32. Qaiyum M, Tyrrell PN, McCall IW, Cassar-Pullicino VN. MRI detection of unsuspected vertebral injury in acute spinal trauma: incidence and significance. Skeletal Radiol 2001;30:299-304

33. Crandall D, Slaughter D, Hankins PJ, Moore C, Jerman J. Acute versus chronic vertebral compression fractures treated with kyphoplasty: early results. Spine J 2004; 4:418-24

34. Brown DB, Gilula LA, Sehgal M, Shimony JS. Treatment of chronic symptomatic vertebral compression fractures with percutaneous vertebroplasty. Am J Roentgenol 2004;182:319-22

35. Berlemann U, Franz T, Orler R, Heini PF. Kyphoplasty for treatment of osteoporotic vertebral fractures: a prospective non-randomized study. Eur Spine J 2004;13:496-501.

36. Grados F, Depriester C, Cayrolle G, et al. Long-term observations of vertebral osteoporotic fractures treated by percutaneous vertebroplasty. Rheumatology 2000; 39:1410-14

37. Diamond TH, Champion B, Clark WA. Management of acute osteoporotic vertebral fractures: a nonrandomized trial comparing percutaneous vertebroplasty with conservative therapy. Am J Med 2003:114:257-65.

38. Weisskopf $\mathbf{M}$, Herlein S, Birnbaum $\mathbf{K}$, et al. Kyphoplasty: a new minimally invasive treatment for repositioning and stabilising vertebral bodies. Z Orthop Ihre Grenzgeb 2003;141:406-11 (in German).

39. Komp M, Ruetten S, Godolias G. Minimally invasive therapy for functionally unstable osteoporotic vertebral fracture by means of kyphoplasty: a prospective comparative study of 19 surgically and 17 conservatively treated patients. J Miner Stoffwechs 2004;1(Suppl 1):13-15 (in German).

40. Kasperk C, Hillmeier J, Noldge G, et al. Prospective controlled study of the treatment of painful osteoporotic vertebral fractures by kyphoplasty. Osteoporos Int 2004; 15(Suppl 1):1-145.

41. Alvarez L, Perez-Higueras A, Quinones D, Calvo E, Rossi RE. Vertebroplasty in the treatment of vertebral tumors: postprocedural outcome and quality of life. Eur Spine J 2003;12:356-60.

42. O'Brien JP, Sims JT, Evans AJ. Vertebroplasty in patients with severe vertebral compression fractures: a technical report. AJNR Am J Neuroradio/ 2000:21:1555-8.

43. Evans AJ, Jensen ME, Kip KE, et al. Vertebral compression fractures: pain reduction and improvement in functional mobility after percutaneous polymethylmethacrylate vertebroplasty: retrospective report of 245 cases. Radiology 2003;226:366-72.

44. Ledlie JT, Renfro M. Balloon kyphoplasty: one-year outcomes in vertebral body height restoration, chronic pain, and activity levels. J Neurosurg Spine 2003;98:36-42.

45. McKiernan F, Jensen R, Faciszewski T. Dynamic mobility of vertebral compression fractures. J Bone Miner Res 2003;18:24-9.

46. Kim DY, Lee SH, Jang JS, Chung SK, Lee HY. Intravertebral vacuum phenomenon in osteoporotic compression fracture: report of 67 cases with quantitative evaluation of intravertebral instability. J Neurosurg Spine 2004;100:24-31

47. Jang JS, Kim DY, Lee SH. Efficacy of percutaneous vertebroplasty in the treatment of intravertebral pseudarthrosis associated with noninfected avascular necrosis of the vertebral body. Spine 2003;28:1588-92.

48. Teng MM, Wei CJ, Wei LC, et al. Kyphosis correction and height restoration effects of percutaneous vertebroplasty. AJNR Am J Neuroradiol 2003;24:1893-900.

49. Hiwatashi A, Moritani T, Numaguchi Y, Westesson PL. Increase in vertebral body height after vertebroplasty. AJNR Am J Neuroradio/ 2003;24:185-9.

50. Phillips FM, Ho E, Campbell-Hupp M, et al. Early radiographic and clinical results of balloon kyphoplasty for the treatment of osteoporotic vertebral compression fractures. Spine 2003;28:2260-7.

51. Weill A, Chiras J, Simon JM, et al. Spinal metastases: indications for and results of percutaneous injection of acrylic surgical cement. Radiol 1996;199:241-7.

52. Heini PF, Walchli B, Berlemann U. Percutaneous transpedicular vertebroplasty with PMMA: operative technique and early results: a prospective study for the treatment of osteoporotic compression fractures. Eur Spine J 2000:9:445-50.

53. Deramond H, Depriester C, Galibert P, Le Gars D. Percutaneous vertebroplasty with polymethylmethacrylate: technique, indications, and results. Radiol Clin North Am 1998:36:533-46.

54. Kallmes DF, Schweickert PA, Marx WF, Jensen ME. Vertebroplasty in the midand upper thoracic spine. AJNR Am J Neuroradio/ 2002;23:1117-20.

55. Yu SW, Chen WJ, Lin WC, Chen YJ, Tu YK. Serious pyogenic spondylitis following vertebroplasty: a case report. Spine 2004;29:209-11.

56. McGraw JK, Lippert JA, Minkus KD, et al. Prospective evaluation of pain relief in 100 patients undergoing percutaneous vertebroplasty: results and follow-up. J Vasc Interv Radiol 2002:13:883-6. 
57. Garfin SR, Yuan HA, Reiley MA. New technologies in spine: kyphoplasty and vertebroplasty for treatment of painful osteoporotic fractures. Spine 2001;26:1511-15.

58. Mousavi P, Roth S, Finkelstein J, Cheung G, Whyne C. Volumetric quantification of cement leakage following percutaneous vertebroplasty in metastatic and osteoporotic vertebrae. J Neurosurg Spine 2003;99:56-9.

59. Ryu KS, Park CK, Kim MC, Kang JK. Dose-dependent epidural leakage of polymethylmethacrylate after percutaneous vertebroplasty in patients with osteoporotic vertebral compression fractures. J Neurosurg Spine 2002;96:56-61.

60. Lee B, Lee S, Yoo T. Paraplegia as a complication of percutaneous vertebroplasty with polymethylmethacrylate: a case report. Spine 2002;27:419-22.

61. Do HM. Intraosseous venography during percutaneous vertebroplasty: is it needed? AJNR Am J Neuroradiol 2002;23:508-9.

62. Gaughen JR, Jensen ME, Schweickert PA, et al. Relevance of antecedent venography in percutaneous vertebroplasty for the treatment of osteoporotic compression fractures. AJNR Am J Neuroradiol 2002;23:594-600

63. Wong W, Mathis JM. Is intraosseous venography a significant safety measure in performance of vertebroplasty? J Vasc Interv Radiol 2002;13:137-8.

64. Bohner M, Gasser B, Baroud G, Heini P. Theoretical and experimental model to describe the injection of a polymethylmethacrylate cement into a porous structure. Biomaterials 2003;24:2721-30.

65. Tsai TT, Chen WJ, Lai PL, et al. Polymethylmethacrylate cement dislodgment following percutaneous vertebroplasty: a case report. Spine 2003;28:457-60.

66. Phillips FM, Todd Wetzel F, Lieberman I, Campbell-Hupp M. An in vivo comparison of the potential for the extravertebral cement leak after vertebroplasty and kyphoplasty. Spine 2002;27:2173-8.

67. Belkoff SM, Mathis JM, Fenton DC, et al. An ex vivo biomechanical evaluation of an inflatable bone tamp used in the treatment of compression fracture. Spine 2001 26:151-6.

68. Aebli N, Krebs J, Davis G, et al. Fat embolism and acute hypotension during vertebroplasty: an experimental study in sheep. Spine 2002;27:460-6.

69. Aebli N, Krebs J, Schwenke D, Davis G, Theis JC. Pressurization in vertebral bodies during vertebroplasty causes cardiovascular complications: an experimental study in sheep. Spine 2003;28:1513-20.

70. Aebli N, Krebs J, Schwenke D, Davis G, Theis JC. Cardiovascular changes during multiple vertebroplasty with and without vent-hole: an experimental study in sheep. Spine 2003;28:1504-12.

71. Kaufmann TJ, Jensen ME, Ford G, et al. Cardiovascular effects of polymethylmethacrylate use in percutaneous vertebroplasty. AJNR Am J Neuroradiol 2002;23 601-4.

72. Coumans JV, Reinhardt MK, Lieberman IH. Kyphoplasty for vertebral compression fractures: 1-year clinical outcomes from a prospective study. J Neursurg Spine 2003:99:44-50.

73. Legroux-Gerot I, Lormeau C, Boutry $\mathbf{N}$, et al. Long-term follow-up of vertebral osteoporotic fractures treated by percutaneous vertebroplasty. Clin Rheumato/ 2004 23:310-17

74. Kim SH, Kang HS, Choi JA, Ahm JM. Risk factors of new compression fractures in adjacent vertebrae after percutaneous vertebroplasty. Acta Radiol 2004;45:440-5.

75. Lin EP, Ekholm S, Hiwatashi A, Westesson PL. Vertebroplasty: cement leakage into the disc increases the risk of new fracture of adjacent vertebral body. AJNR Am J Neuroradiol 2004;25:175-80.

76. Lindsay R, Silverman SL, Cooper C, et al. Risk of new vertebral fracture in the year following a fracture. JAMA 2001;285:320-3.

77. Silverman SL, Minshall ME, Shen $\mathbf{W}$, et al. The relationship of health-related quality of life to prevalent and incident vertebral fractures in postmenopausal women with osteoporosis: results from the multiple outcomes of raloxifene evaluation study. Arthritis Reum 2001:44:2611-19.

78. Eck JC, Humphreys SC, Hodges SD. Adjacent-segment degeneration after lumbar fusion: a review of clinical, biomechanical, and radiologic studies. Am J Orthop 1999, 28:336-40

79. Berlemann U, Ferguson SJ, Nolte LP, Heini PF. Adjacent vertebral failure after vertebroplasty: a biomechanical investigation. J Bone Joint Surg [Br]2002;84-B:748-52.

80. Tomita S, Kin A, Yazu M, Abe M. Biomechanical evaluation of kyphoplasty and vertebroplasty with calcium phosphate cement in a simulated osteoporotic compression fracture. J Orthop Sci 2003;8:192-7.

81. Belkoff SM, Mathis JM, Erbe EM, Fenton DC. Biomechanical evaluation of a new bone cement for use in vertebroplasty. Spine 2000;25:1061-4.

82. Heini PF, Berlemann U, Kaufmann M, et al. Augmentation of mechanical properties in osteoporotic vertebral bones: a biomechanical investigation of vertebroplasty efficacy with different bone cements. Eur Spine J 2001;10:164-71

83. Molloy S, Mathis JM, Belkoff SM. The effect of vertebral body percentage fill on mechanical behavior during percutaneous vertebroplasty. Spine 2003;28:1549-54

84. Belkoff SM, Mathis JM, Jasper LE, Deramond H. The biomechanics of vertebroplasty: the effect of cement volume on mechanical behaviour. Spine 2001;26:1537-41.
85. Liebschner MA, Rosenberg WS, Keaveny TM. Effects of bone cement volume and distribution on vertebral stiffness after vertebroplasty. Spine 2001;26:1547-54.

86. Tohmeh AG, Mathis JM, Fenton DC, Levine AM, Belkoff SM. Biomechanica efficacy of unipedicular versus bipendicular vertebroplasty for the management of osteoporotic compression fractures. Spine 1999;24:1772-6.

87. Mehdizade A, Lovblad KO, Wilhelm KE, et al. Radiation dose in vertebroplasty Neuroradiology 2004;46:243-5.

88. Theocharapoulos $\mathbf{N}$, Perisinakis $\mathbf{K}$, Damilakis $\mathbf{J}$, et al. Occupational exposure from common fluoroscopic projections used in orthopaedic surgery. J Bone Joint Surg [Am] 2003;85-A:1698-703.

89. Kruger R, Faciszewski T. Radiation dose reduction to medical staff during vertebroplasty: a review of techniques and methods to mitigate occupational dose. Spine 2003:28:1608-13

90. Kallmes DF, 0 E, Roy SS, Piccolo RG, et al. Radiation dose to the operator during vertebroplasty: prospective comparison of the use of 1-cc syringes versus an injection device. AJNR Am J Neuroradio/ 2003;24:1257-60.

91. Perisinakis $\mathbf{K}$, Damilakis $\mathbf{J}$, Theocharopoulos $\mathbf{N}$, et al. Patient exposure and associated radiation risks from fluoroscopically guided vertebroplasty and kyphoplasty. Radiology 2004;232:701-7

92. Barrett-Connor E. The economic and human costs of osteoporotic fracture. Am J Med 1995;98:3-8

93. Yuan HA, Brown CW, Phillips FM. Osteoporotic spinal deformity: a biomechanica rationale for the clinical consequences and treatment of vertebral body compression fractures. J Spinal Disord Tech 2004;17:236-42.

94. Ortiz A0, Zoarski GH, Beckerman M. Kyphoplasty. Tech Vasc Interv Radio/ 2002 5:239-49.

95. McKiernan F, Faciszewski T, Jensen R. Reporting height restoration in vertebra compression fractures. Spine 2003;28:2517-21.

96. Hillmeier JS, Meeder PJ, Noledge G, Kasperk C. Minimally invasive reduction and stabilization of osteoporotic vertebral body fractures (balloon kyphoplasty) Operat Orthop Traumatol 2003;15:343-63.

97. Fisher A. Percutaneous vertebroplasty: a bone cement procedure for spinal pain relief: Canadian Coordinating Office for Health Technology Assessment (CCOHTA) 2002 http://www.ccohta.ca/publications/PDF/196_vertebroplasty_cetap_e.PDF laccessed 28/10/05)

98. Martin JB, Jean B, Sugiu K, et al. Vertebroplasty: clinical experience and followup results. Bone 1999;25(2 Suppl):11-15.

99. Barr JD, Barr MS, Lemley TJ, McCann RM. Percutaneous vertebroplasty for pain relief and spinal stabilization. Spine 2000;25:923-8.

100. Maynard AS, Jensen ME, Schweickert PA, et al. Value of bone scan imaging in predicting pain relief from percutaneous vertebroplasty in osteoporotic vertebra fractures. AJNR Am J Neuroradio/ 2000;21:1807-12.

101. Amar AP, Larsen DW, Esnaashari N, et al. Percutaneous transpedicular polymethylmethacrylate vertebroplasty for the treatment of spinal compression fractures. Neurosurgery 2001;49:1105-14.

102. Moreland DB, Landi MK, Grand W. Vertebroplasty: techniques to avoid complications. Spine J 2001;1:66-71.

103. Kaufmann TJ, Jensen ME, Schweickert P, Marx WF, Kallmes DF. Age of fracture and clinical outcomes of percutaneous vertebroplasty. AJNR Am J Neuroradiol 2001;22:1860-3

104. Peh WC, Gilula LA, Peck DD. Percutaneous vertebroplasty for severe osteoporotic vertebral body compression fractures. Radiology 2002;223:121-6.

105. Zoarski GH, Snow P, Olan WJ, et al. Percutaneous vertebroplasty for osteoporotic compression fractures: quantitative prospective evaluation of long-term outcomes. $J$ Vas Interv Radio/ 2002;13:139-48.

106. Nakano M, Hirano N, Matsura K, et al. Percutaneous transpedicular vertebroplasty with calcium phosphate cement in the treatment of osteoporotic vertebra compression and burst fractures. J Neurosurg Spine 2002;97:287-93.

107. Perez-Higueras A, Alvarez L, Rossi R, Quinones D, Al-Assir I. Percutaneous vertebroplasty: Iong-term clinical and radiological outcome. Neuroradiology2002;44:950-4.

108. Gangi A, Guth S, Imbert JP, Marin H, Dietermann JL. Percutaneous vertebroplasty: indications, technique, and results. Radiographics 2003;23:10.

109. Chen LH, Niu CC, Yu SW, et al. Minimally invasive treatment of osteoporotic vertebral compression fracture. Chang Gung Med J 2004;27:261-7.

110. Winking M, Stahl JP, Oertel M, Schnettler R, Boker DK. Treatment of pain from osteoporotic vertebral collapse by percutaneous PMMA vertebroplasty. Acta Neurochir (Wien) 2004;146:469-76.

111. Cortet B, Cotten A, Boutry N, et al. Percutaneous vertebroplasty in patients with osteolytic metastases or multiple myeloma. Rev Rhum Engl Ed 1997;64:177-83.

112. Winking M, Stahl JP, Oertel M, Schnettler R, Boker DK. Polymethylmethacrylate-vertebroplasty: a new and effective method of pain treatment in vertebral compression. Dtsch Med Wochenschr 2003;128:2525-30 (in German). 
113. Kim AK, Jensen ME, Dion JE, et al. Unilateral transpedicular percutaneous vertebroplasty: initial experience. Radiology 2002;222:737-41.

114. Hodler J, Peck D, Gilula LA. Midterm outcome after vertebroplasty: predictive value of technical and patient-related factors. Radiology 2003;227:662-8.

115. Theodorou DJ, Theodorou SJ, Duncan TD, Garfin SR, Wong WH. Percutaneous balloon kyphoplasty for the correction of a spinal deformity in painful vertebral compression fractures. Clin Imaging 2002;26:1-5.

116. Wong WH, Olan WJ, Belkoff SM. Balloon kyphoplasty. In: Mathis JM, Deramond H, Belkoff SM, eds. Percutaneous vertebroplasty. New York: Springer-Verlag, 2002: $109-24$

117. Wilhelm K, Stoffel M, Ringel F, et al. Preliminary experience with balloon kyphoplasty for the treatment of painful osteoporotic compression fractures. Rofo 2003; 177:1690-6 (in German).

118. Hillmeier J, Grafe I, Da Fonseca K, et al. The evaluation of balloon kyphoplasty for osteoporotic vertebral fractures: an interdisciplinary concept. Orthopade 2004;33: 893-904 (in German).

119. Rhyne A 3rd, Banit D, Laxer E, Odum S, Nussman D. Kyphoplasty: report of eighty-two thoracolumbar osteoporotic vertebral fractures. J Orthop Trauma 2004;18: 294-9.

120. Lee ST, Chen JF. Closed reduction vertebroplasty for the treatment of osteoporotic vertebral compression fractures: technical note. J Neurosurg Spine 2004;100(Suppl 4):392-6.

121. Wong W, Reiley MA, Garfin S. Vertebroplasty/kyphoplasty. J Women's Imaging 2000;2:117-24.

122. Lane JM, Girardi F, Parvataneni H, et al. Preliminary outcomes of the first 226 consecutive kyphoplasties for the fixation of painful osteoporotic vertebral compression fractures [abstract]. Osteoporos Int 2000;11(Suppl 2):206.

123. Lane JM, Hong $\mathbf{R}$, Koob J, et al. Kyphoplasty enhances function and structural alignment in multiple myeloma. Clin Orthop 2004;426:49-53.

124. Yeom JS, Kim WJ, Choy WS, et al. Leakage of cement in percutaneous vertebroplasty for painful osteoporotic compression fractures. J Bone Joint Surg [Br] 2003; 85-B:83-9.

125. Wenger M, Markwalder TM. Surgically controlled, transpedicular methyl methacrylate vertebroplasty with fluoroscopic guidance. Acta Neurochir (Wien) 1999;141: 625-31.

126. Tsou I, Goh P, Peh W, Goh L, Chee T. Percutaneous vertebroplasty in the management of osteoporotic vertebral compression fractures: initial experience. Ann Acad Med Singapore 2002;31:15-20.

127. Jang JS, Lee SH, Jung SK. Pulmonary embolism of polymethylmethacrylate after percutaneous vertebroplasty: a report of three cases. Spine 2002;27:416-18.

128. Padovani B, Kasriel O, Brunner P, Peretti-Viton P. Pulmonary embolism caused by acrylic cement: a rare complication of percutaneous vertebroplasty. AJNR Am J Neuroradiol 1999;20:375-7

129. Tozzi P, Abdelmoumene Y, Corno AF, et al. Management of pulmonary embolism during acrylic vertebroplasty. Ann Thorac Surg 2002;74:1706-8.

130. Chen HL, Wong CS, Ho ST, et al. A lethal pulmonary embolism during percutaneous vertebroplasty. Anesth Analg 2002;95:1060-2.

131. Scroop R, Eskridge J, Britz GW. Paradoxical cerebral artery embolization of cement during intraoperative vertebroplasty: a case report. AJNR Am J Neuroradiol 2002:23:868-70.
132. Francois K, Taeymans Y, Poffyn B, Van Nooten G. Successful management of large pulmonary cement embolus after percutaneous vertebroplasty: a case report. Spine 2003;28:424-5

133. Bernhard J, Heini PF, Villiger PM. Asymptomatic diffuse pulmonary embolism caused by acrylic cement: an unusual complication of percutaneous vertebroplasty. Ann Rheum Dis 2003;62:85-6.

134. Yoo KY, Jeong SW, Yoon W, Lee J. Acute respiratory distress syndrome associated with pulmonary cement embolism following percutaneous vertebroplasty with polymethylmethacrylate. Spine 2004;29:294-7.

135. Stricker K, Orler R, Yen K, Takala J, Luginbuhl M. Severe hypercapnia due to pulmonary embolism of polymethylmethacrylate during vertebroplasty. Anesth Analg 2004:98:1184-6

136. Pleser M, Roth R, Worsdorfer O, Manke C. Pulmonary embolism caused by PMMA in percutaneous vertebroplasty: case report and review of the literature. Unfallchirurg 2004;107:807-11 (in German).

137. Charvet A, Metellus P, Bruder N, et al. Pulmonary embolism of cement during vertebroplasty. Ann Fr Anesth Reanim 2004;23:827-30 (in French).

138. Temple JD, Ludwig SC, Ross WK, et al. Catastrophic fat embolism following augmentation of pedicle screws with bone cement: a case report. J Bone Joint Surg [Am] 2002;84-A:639-42

139. Harrington KD. Major neurological complications following percutaneous vertebroplasty with polymethylmethacrylate: a case report. J Bone Joint Surg [Am] 2001; 83-A:1070-3

140. Ratliff J, Nguyen T, Heiss J. Root and spinal cord compression from methylmethacrylate vertebroplasty. Spine 2001;26:300-2.

141. Shapiro S, Abel T, Purvines S. Surgical removal of epidural and intradural polymethylmethacrylate extravasation complicating percutaneous vertebroplasty for an osteoporotic lumbar compression fracture: case report. J Neurosurg Spine 2003;98: 90-2.

142. Cohen JE, Lylyk $\mathbf{P}$, Ceratto $\mathbf{R}$, et al. Percutaneous vertebroplasty: technique and results in 192 procedures. Neurol Res 2004;26:41-9.

143. Uppin A, Hirsch J, Centenera L, et al. Occurrence of new vertebral fracture after percutaneous vertebroplasty in patients with osteoporosis. Radiology 2003;226:119-24.

144. Lieberman IH, Reinhardt MK. Vertebroplasty and kyphoplasty for osteolytic vertebral collapse. Clin Orthop 2003;415(Suppl):176-86.

145. Fribourg D, Tang C, Delamarter R, Bae Hyun. Incidence of subsequent vertebral fracture after kyphoplasty. Spine J 2004;29:2270-6.

146. Harrop JS, Prpa B, Reinhardt MK, Lieberman I. Primary and secondary osteoporosis: incidence of subsequent vertebral compression fractures after kyphoplasty. Spine 2004;29:2120-5

147. Belkoff SM, Maroney M, Felton DC, Mathis JM. An in vitro biochemical evaluation of bone cements used in percutaneous vertebroplasty. Bone 1999;25(Suppl 2): 23-6

148. Belkoff SM, Marthis JM, Jasper LE, Deramond H. An ex vivo biochemical evaluation of hydroxyapatite cement for use with vertebroplasty. Spine 2001;26:1542-6.

149. Lim TH, Brebach GT, Renner SM, et al. Biomechanical evaluation of an injectable calcium phosphate cement for vertebroplasty. Spine 2002;27:1297-302.

150. Belkoff SM, Mathis JM, Deramond H, Jasper LE. An ex vivo biomechanical evaluation of hydroxyapatite cement for use with kyphoplasty. AJNR Am J Neuroradiol 2001:22:1212-16 